\title{
Evaluation of small hydropower plant at Ribb irrigation dam in Amhara regional state, Ethiopia
}

\author{
Addisu Worku Bezabih*
}

\begin{abstract}
Background: Energy is the main requirement for economic growth in any country and supports the modern economy. The energy sector is considered a vital element in developing countries because it meets energy needs. This article addresses the production of electricity using small hydroelectric power plants for rural applications. The main objective of this study was to assess the potential of the Ribb dam for small hydroelectric plants. The flow is very important for the production of hydroelectricity as the height of a proposed site is constant and the available flow is very variable.

Result: The flow duration curve is constant and it will vary from 20 to $50 \%$ from the nominal flow. Further, it will decrease when the percentage of the nominal flow increases. The best size of a small hydroelectric plant producing a maximum of electricity in the context of future projected flows in the study region. Further, the Ribb dam concluded that the average flow of $14.6331 \mathrm{~m}^{3} / \mathrm{s}$, the smooth head of $70.37 \mathrm{~m}$, and the average nominal power of $5.53 \mathrm{MW}$.
\end{abstract}

Conclusion: Small hydro system (SHP) is a promising alternative for the production of cheap and renewable energy in rural or developing areas.

Keywords: Flow duration curve, Ribb dam, Small hydroelectricity power, Ethiopia

\section{Introduction}

Electrical energy is becoming an essential commodity for modern life today. All sectors, such as industry, technology, transport, public services or family life, are now entirely dependent on electricity. The dependence on electric power is increasing, which has led to an increase in its demand. Electricity is a fundamental element that is essential to the development of a country Khan et al. (2016). Renewable energy, like sunlight, wind, rain, tides, waves, and geothermal heat, is that the energy that's obtained from renewable resources which are naturally replenished on somebody's continuance. In four important areas, renewable energy also provides energy: power

*Correspondence: addisu2116@gmail.com

Department of Electrical and Computer Engineering, Debre Tabor University, Debre Tabor, Ethiopia generation, air and water heating/cooling, transport, and rural (off-grid) energy services (Table 1, Fig. 1).

All modern living conditions of mankind quickly depend on electricity. Water, colloquially called "white oil" from Ethiopia, has the enormous uncured ability to inevitably change the capacity of this developing country to industrialize. Ethiopia ranks the second in terms of economically feasible hydroelectric production among all African countries, with an approximate capacity of 30,000 MW only for the Democratic Republic of Congo Bartle (2002).

In Ethiopia we project a high level of hydroelectric production between 71 and $87 \mathrm{TWh} /$ year by 2050 under the strict climate change mitigation scenario. This makes the country towards significant contribution to the global efforts to reach the $2{ }^{\circ} \mathrm{C}$ target set by the Paris Agreement (Christoff 2016). Although the country's population and demand for energy is growing rapidly, electricity 
Table 1 Energy Resource Potential of Ethiopia (June 22, 2013) (Derbew 2013)

\begin{tabular}{|c|c|c|c|c|c|}
\hline & \multirow[t]{2}{*}{ Resource } & \multirow[t]{2}{*}{ Unit } & \multirow{2}{*}{$\begin{array}{l}\text { Exploitable } \\
\text { reserve }\end{array}$} & \multicolumn{2}{|c|}{ Exploited } \\
\hline & & & & Amount & Present \\
\hline 1 & Hydropower & MW & 45,000 & 2100 & $<5 \%$ \\
\hline 2 & Solar/day & $\mathrm{KWH} / \mathrm{M}^{2}$ & 6 & - & $<1 \%$ \\
\hline 3 & $\begin{array}{l}\text { Wind: power } \\
\text { speed }\end{array}$ & $\mathrm{GW}(\mathrm{m} / \mathrm{s})$ & 1350 & $171 \mathrm{MW}$ & - \\
\hline 4 & Geothermal & MW & 7000 & - & - \\
\hline 5 & Wood & Million tones & 1120 & $7.3 \mathrm{MW}$ & $50 \%$ \\
\hline 6 & $\begin{array}{l}\text { Agricultural } \\
\text { waste }\end{array}$ & Million tones & $15-20$ & 560 & $30 \%$ \\
\hline 7 & Natural gas's & Million tones & 113 & 6 & $0 \%$ \\
\hline 8 & COAL & Billion $\mathrm{m}^{3}$ & 300 & - & $0 \%$ \\
\hline 9 & Oil shale & Million tones & 253 & - & $0 \%$ \\
\hline
\end{tabular}

production and access to it has been one of the lowest in the world (Woldemariam 2004) (Tables 2, 3).

In this case, the power plant can be located at the foot of the dam or at any other suitable place upstream of the collection dam using complete electricity generation irrigation systems subject to temporary irrigation requirements (Kumar and Shankar 2009). Hydroelectric power is a clean, economical, non-polluting, and a source of sustainable energy for the environment. Hydroelectric power plants help increase the efficiency of the electricity system. Some hydroelectric projects have a long lifespan of more than 50 years and contribute to the overall conservation of rare fossil fuels (Yüksel 2009).

One of the renewable energy technologies for electricity and mechanical energy production is the small hydro system (SHP) and classified as "thin" as per the capacity of the electricity installed. There is no international agreement on the "small" limit, but the most European countries and others accept $10 \mathrm{MW}$ as the upper limit (ESHA 2004). The systems are further classified within the SHP group as Pico, Medium, Mini and Small Systems (Kaunda et al. 2012) (Fig. 2). The construction of small hydroelectric projects is a safer choice than a large hydroelectric project to control and use water supplies in a sustainable manner without adverse socio-economic and environmental impact (Kumar 2018). The development of small hydropower plants will reduce energy imbalances (Girma 2016).

River Ribb comes from the southern part of the Gondar zone around Guna Mountain. It flows to the west, crossing Libo kemkem Woreda and reaching Lake Tana. There was an irrigation dam, which is expected to grow from approximately 14,460 ha of land from the small hydroelectric power plants. In some cases, feeding directly to the small and medium industries such as cement and fertilizer factories. Small hydro in rural areas is widely used for residential lighting, television, radio and telephone services. It also provides the energy for small factories, fishing and other important uses. Thus, the Ethiopian government should develop a sustainable electricity capacity with low environmental risk and reduce transport and distribution losses by using good techniques and labor and timely and adequate electricity supply.

Small hydropower (SHP) has emerged as an energy source that is accepted as being renewable, easily developed, inexpensive, and harmless to the environment. The general objective of this study is to assess and evaluate the hydroelectric capacity of existing Ribb dam which is located in the Amhara region of Ethiopia. This suggests the production of multipurpose water resources for better economic gain. The fundamental goal was to move towards estimating energy production as it would benefit the economy and society.

\section{Materials and methods}

Research area, tools and processes used to test and improve existing dams for electricity production.

\section{Description of the area of study}

The Ribb dam is located in the river Ribb in South Gondar zone of the National Regional State of Amhara, on the east side of the sub-basin of Lake Tana. The Ribb River approximately $130 \mathrm{~km}$ long and has a drainage area of approximately $1790 \mathrm{~km}^{2}$ with an annual average discharge of $14.6331 \mathrm{~m}^{3} / \mathrm{s}$. It has catchment area of about $685 \mathrm{~km}^{2}$ on the dam site. The axis of the dam is located between the geographic reference grids. UTM E 392,174.64, N 1,330,225.76 and $\mathrm{E} 390,813.45, \mathrm{~N} 1,330,018$ 0.02, at altitudes between $1880 \mathrm{~m}$ and $1,970 \mathrm{~m}$. The left pinnacle is at an altitude of $1943 \mathrm{~m}$ to, the middle of the axis of the dam with an altitude of $1873 \mathrm{~m}$ and the right pinnacle is at an altitude of $1966 \mathrm{~m}$. High-Ribb watershed is characterized as a turning point (3.6 percent) of mountain, and it will be in the form of corner and steep-slope. The southeastern part the highest elevation of the watershed is about $4,100 \mathrm{~m}$. The lowest topography is on the dam site, at $1873 \mathrm{~m}$ above sea level. The climate of the Ribb basin is characterized by rainy season which starts from May to July. The monthly precipitation varying from $65 \mathrm{~mm}$ in May to $411 \mathrm{~mm}$ in July. The average annual precipitation recorded is approximately $1,400 \mathrm{~mm}$ and at the lowest is approximately $1,200 \mathrm{~mm}$. Throughout the year the temperature varies from $19{ }^{\circ} \mathrm{C}$ (in December) to $23{ }^{\circ} \mathrm{C}$ (in May) and will experience maximum temperature is about $30{ }^{\circ} \mathrm{C}$ and minimum temperature is about $11.5^{\circ} \mathrm{C}$. The wind speed is low and reducing the possible evapotranspiration values between December $(95 \mathrm{~mm} /$ month) 
and April (140 mm/month). The amount of sunlight is reduced to $6.0 \mathrm{~h}$ in July and $6.5 \mathrm{~h}$ in August (Figs. 1 and 2).

\section{Description of input data}

Data collection techniques for primary and secondary data were collected from various sources and analyzed using GIS, spread sheet Excel, and MATLAB. The main data come from topographic, hydrological, geological, studies and materials. To understand water discharges, the annual energy production of the proposed site can be estimated, which will be used as input energy to power the hydraulic turbine of the SHP electricity production system. Analyzing the demand for water for hydroelectricity means compiling and analyzing flow data, since the total quantity available on a site is used in the production of electricity. The flow is therefore an important parameter in deciding the potential power that can be derived from any flowing river. The production of hydroelectric power leads to a sustainable climate and a better standard of social life. The results of the study will form the basis for further analysis to support a reasoned decision to further assess the capacity of a site to be served. The electrical energy generated by a small hydroelectric plant would be able to meet the community's needs for irrigation flows. The system used in

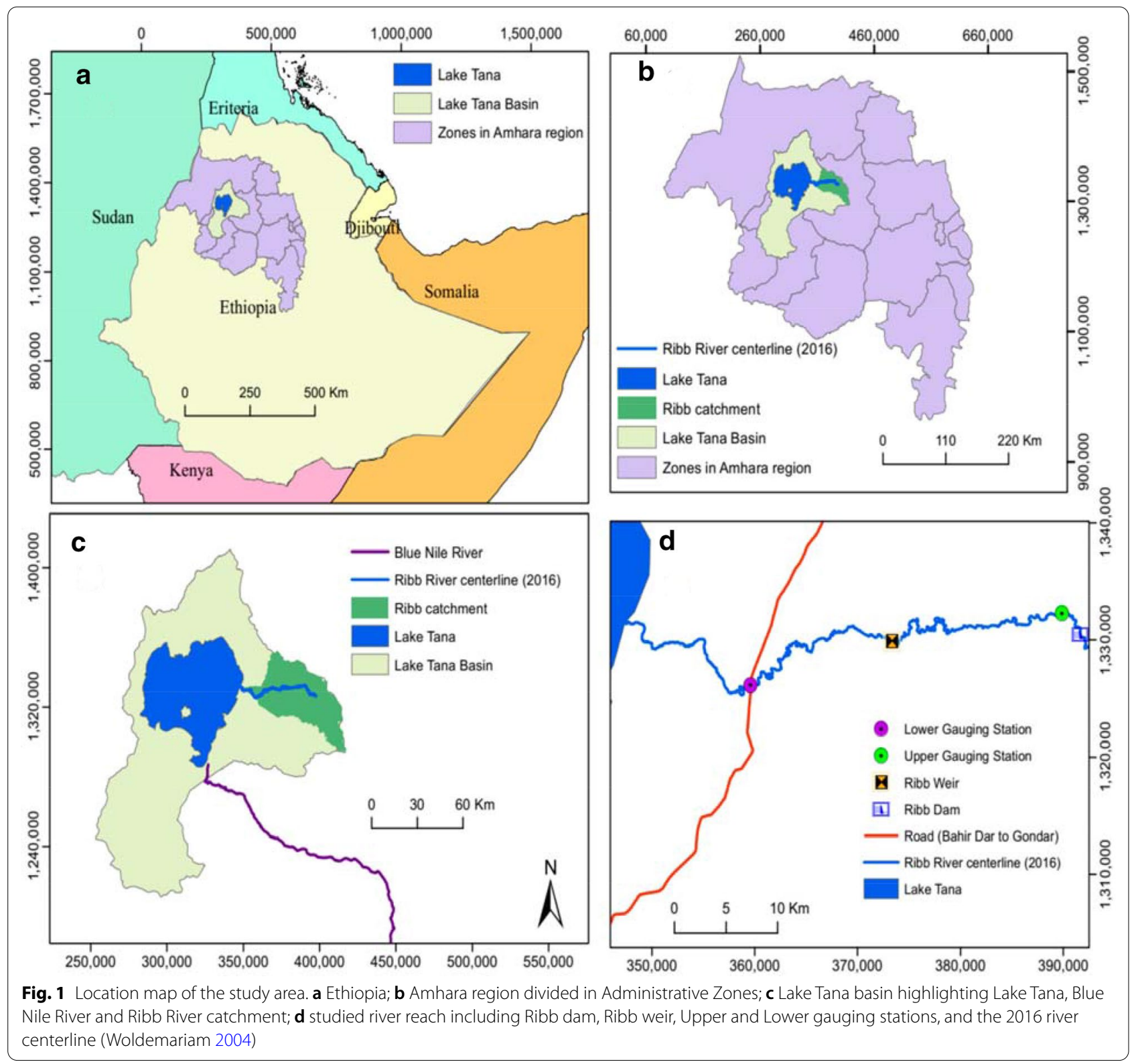




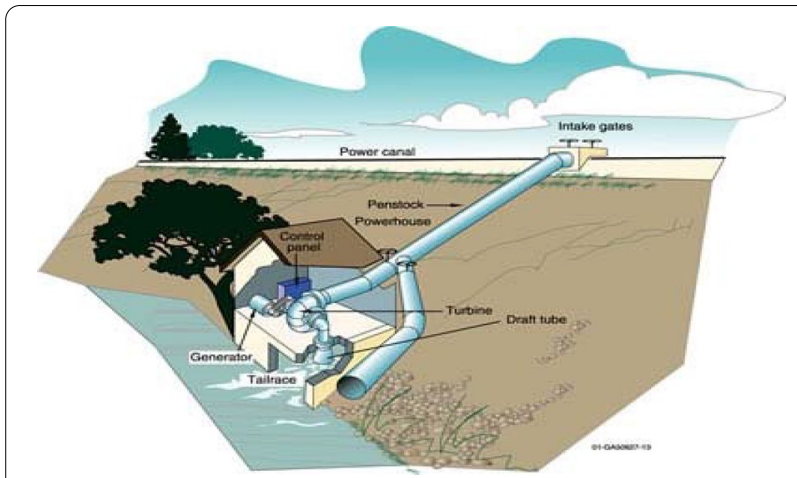

Fig. 2 Study area location of turbine (Kaunda et al. 2012)

this research included several stages in the use of irrigation flow for the production of small hydroelectric plants (Tables 2, 3).

\section{Methodology}

The methodology estimating the capacity for energy production and the assessment of economic profitability (Du et al. 2017) is as follows, although only the first step is considered in this paper. The sites' power potential was calculated from a reliable average monthly flow and heads for different time scales. The generation potential energy depends primarily on the available flow and topographical hydraulic head (Kaunda et al. 2012).

$$
P=Q \rho \eta g H
$$

where, $p$ is the power; $\rho$ is the water density, $g$ is gravity, $\mathrm{Q}$ is discharged equally to $75 \%$ effective flow, and $\mathrm{H}(\mathrm{m})$ is the net head (Fraenkel et al. 1991) (Table 4, Fig. 3). Hydroelectricity is the power generated by flowing water using the potential energy it contains. It
Table 3 Rib annual maximum, mean and minimum flow data (Woldemariam 2004)

\begin{tabular}{llll}
\hline Year & Maximum $\left(\mathbf{m}^{\mathbf{3}} / \mathbf{s}\right)$ & Mean $\left(\mathbf{m}^{\mathbf{3}} / \mathbf{s}\right)$ & Minimum $\left(\mathbf{m}^{\mathbf{3}} / \mathbf{s}\right)$ \\
\hline 1998 & 70.214 & 15.148 & 0.124 \\
1999 & 94.544 & 11.841 & 0.106 \\
2000 & 90.729 & 13.557 & 0.156 \\
2001 & 86.915 & 15.274 & 0.206 \\
2002 & 77.117 & 9.034 & 0.066 \\
2003 & 84.411 & 14.674 & 0.000 \\
2004 & 89.561 & 11.007 & 0.001 \\
2005 & 90.818 & 14.933 & 0.000 \\
2006 & 94.224 & 19.234 & 0.000 \\
2007 & 95.486 & 21.629 & 2.547 \\
Average & 87.4019 & 14.6331 & 0.3206 \\
\hline
\end{tabular}

is a renewable energy source suitable for rural electrification in developing countries such as ours. Conceptually, the equation generally used to determine the output power based on flow and head is (Sule et al. 2011). Annual values are between the highest and lowest rates. Second, using the Weibull method, the graduated dataset was converted to probabilities.

$$
P=\frac{m}{n+1} * 100 \%
$$

Or; $\mathrm{P}=$ the probability equal to or greater than a given flow (percentage of the duration), $\mathrm{m}$ is the estimate of a given flow, and $\mathrm{n}$ is the total number of records.

In general, the flow period curve is very useful in hydrological analyzes, particularly in hydroelectric studies. The flow length curve (FDC) can be used in the hydroelectric study to calculate the expected power of a planned hydroelectric installation (Fritz 1984). Two methods can be used to calculate a flow length curve at a

\begin{tabular}{|c|c|c|c|c|c|c|c|c|c|c|c|}
\hline Year/Month & Jan & Feb & Mar & Apr & May & Jun & Jul & Aug & Sep & Oct & Nov \\
\hline 1998 & 0.707 & 0.318 & 0.258 & 0.175 & 1.288 & 3.856 & 48.36 & 66.479 & 43.012 & 12.401 & 3.983 \\
\hline 1999 & 0.805 & 0.491 & 0.363 & 0.298 & 0.386 & 3.416 & 45.272 & 70.812 & 39.862 & 41.027 & 12.955 \\
\hline 2000 & 5.046 & 0.467 & 0.303 & 0.987 & 0.682 & 2.009 & 40.953 & 72.013 & 35.076 & 16.198 & 5.193 \\
\hline 2001 & 0.803 & 0.481 & 0.492 & 0.427 & 0.531 & 15.312 & 57.551 & 73.215 & 26.7 & 5.056 & 1.844 \\
\hline 2002 & 0.543 & 0.284 & 0.286 & 0.452 & 0.13 & 7.594 & 22.828 & 46.646 & 24.059 & 3.115 & 1.243 \\
\hline 2003 & 0.704 & 0.509 & 0.565 & 0.131 & 0.062 & 3.974 & 44.273 & 65.973 & 44.303 & 8.415 & 4.071 \\
\hline 2004 & 1.619 & 1.32 & 1.016 & 1.767 & 1.188 & 3.732 & 36.825 & 54.914 & 19.645 & 5.796 & 2.601 \\
\hline 2005 & 1.293 & 0.88 & 1.585 & 0.627 & 0.955 & 9.082 & 44.826 & 60.456 & 40.669 & 10.574 & 4.841 \\
\hline 2006 & 2.508 & 1.963 & 0.56 & 0.758 & 4.998 & 10.279 & 48.824 & 77.908 & 52.278 & 15.246 & 8.555 \\
\hline 2007 & 5.686 & 4.834 & 3.594 & 4.967 & 6.626 & 19.706 & 62.154 & 75.24 & 50.145 & 12.459 & 8.041 \\
\hline Average & 1.9714 & 1.1547 & 0.9022 & 1.0589 & 1.6846 & 7.896 & 45.1866 & 66.3656 & 37.5749 & 13.0287 & 5.3327 \\
\hline
\end{tabular}

Table 2 Yearly/Monthly discharge flow data of the Rib River (Woldemariam 2004) 
calibrated point: the graduated flow method and the class interval method. Dominant runoff processes, including soil storage and drainage capacity, affect flow duration curves where watersheds with large storage have duration curves different from those of small storage basins (Floriancic et al. 2016).

\section{Results and discussion}

The power thus is a part of the South Gonder Libo Kemkem is in need of power and host communities. On the basis of the available gross head, the estimated hydraulic flows and losses as well as the characteristics of the turbines were determined; the amount of annual energy production was generated from the selected hydroelectric sites. Hydroelectricity is the most important type of renewable and sustainable electricity today (Binder 2000). Hydroelectricity is the production of electricity by harnessing the energy of moving water. By converting hydraulic energy into mechanical energy, the latest commercially available technologies produce electricity to trigger a turbine connected to a generator (Quigley 2013) (Table 5).

Annual power $=\mathrm{P} * 24 \mathrm{~h} * 365$ days.

Annual energy consumption ( $\mathrm{kWh})$ is

$$
E=P H C_{F}
$$

where, $\mathrm{P}=$ power (kilowatts), $\mathrm{H}=$ annual period $(8760 \mathrm{~h}$ per year) and $\mathrm{C}_{\mathrm{F}}=$ plant capacity factor ( $95 \%$ for types of hydroelectric plants). Thus, a potentially good SHP site should have a high head and a high throughput. This implies that a hilly area with free flowing rivers generally generates high resistance.

The data obtained on the Ribb dam are the maximum, minimum and average annual flows in Table 2. Multiply the measured power value by a given quantity called the correction factor. In general, for rocky and non-rocky streams, correction factor values of 0.65 and 0.85 are used. However, an average value of 0.75 is generally used for statistical purposes. The efficiencies of penstocks, turbines, and generators are $0.95,0.90$, and 0.85 , respectively (Table 4 and 5).

Gross head $=73.3 \mathrm{~m}$, hydraulic loss $=4 \%$ of gross head.

Net height $=$ gross height - hydraulic loss $=70.37 \mathrm{~m}$.

The average annual maximum, minimum and average releases were $87.4019 \mathrm{~m}^{3} / \mathrm{sec}, 0.3206 \mathrm{~m}^{3} / \mathrm{sec}$ and $14.6331 \mathrm{~m}^{3} / \mathrm{s}$ respectively.

The average annual total runoff volume $=14.6331 \mathrm{~m}^{3} / \mathrm{s}$ * $60 \mathrm{~min} * 60 \mathrm{~s} * 24 \mathrm{~h} * 365$ days $=0.46 \times 10^{9} \mathrm{~m}^{3}$ (Figs. 3 and 4).

Figure 5 depicts that the flow duration curve is constant from the nominal flow from 20 to $50 \%$, and then decreases as the percentage of the nominal flow increases.
Table 4 Power, available power and annual output energy of different discharge flow (Fraenkel et al. 1991)

\begin{tabular}{llll}
\hline Discharge flow (Q) & Power (kw) & $\begin{array}{l}\text { Available } \\
\text { Power } \\
\text { (MW) }\end{array}$ & $\begin{array}{l}\text { Annual } \\
\text { output } \\
\text { energy (kwh) }\end{array}$ \\
\hline $\begin{array}{l}\text { Maximum } \\
\left(\mathrm{Q}=87.4019 \mathrm{~m}^{3} / \mathrm{s}\right)\end{array}$ & $44,045.373$ & 33.034 & $274,909.196$ \\
Minimum $\left(\mathrm{Q}=0.3206 \mathrm{~m}^{3} / \mathrm{s}\right)$ & 61.56 & 0.12 & 1.008 \\
Average $\left(\mathrm{Q}=14.6331 \mathrm{~m}^{3} / \mathrm{s}\right)$ & $7,374,214$ & $5.53 \mathrm{MW}$ & $46,026.159$ \\
\hline
\end{tabular}

Table 5 Average mean flow discharge and power potential of the Ribb River (Quigley 2013)

\begin{tabular}{llr}
\hline Month & $\begin{array}{l}\text { Mean flow discharge } \\
(\mathbf{L} / \mathbf{s})\end{array}$ & Power potential (kW) \\
\hline Jan & $1,971.4$ & 993.467 \\
Feb & $1,154.7$ & 581.900 \\
Mar & 902.2 & 454.655 \\
Apr & $1,058.9$ & 533.623 \\
May & $1,684.6$ & 848.938 \\
Jun & 7,896 & 3975.059 \\
Jul & $45,186.6$ & $22,771.365$ \\
Aug & $66,365.6$ & $33,444.318$ \\
Sep & $37,574.9$ & $18,935.516$ \\
Oct & $13,028.7$ & $6,565.690$ \\
Nov & $5,332.7$ & $2,687.364$ \\
Dec & 3,883 & $1,956.800$ \\
Average & $15,503.28$ & 7812.391 \\
\hline
\end{tabular}

Another way to organize flow data is to plot the flow duration curve (FDC). An FDC shows the proportion of time that the flow is equal to or greater than certain values for a particular point on a river. In general, the flow period curve is very useful in hydrological analyzes particularly in hydroelectric studies. The flow duration curve (FDC) can be used in the hydroelectric study to calculate the expected power of a planned hydroelectric installation (Fritz 1984) (Fig. 4).

The "Flow Exceedance" curve or the "Percent Exceeds" curve represents the rating or the amount of times in percent a given value of river flow is equaled or exceeded. This graph is helpful for setting the turbine flow and calculate the quantity of energy that might be produced. A small hydroelectric plant generates energy that depends on flow and head. The head in a small hydroelectric plant is generally constant, as run-of-river plants have a fixed level of upstream water. However, the available speed can be quite variable. Minimum flow is deemed to exceed $100 \%$ of the time while the maximum flow exceeds $0 \%$ of the time. An efficient flow of 90 percent, therefore, means that the flow is greater 


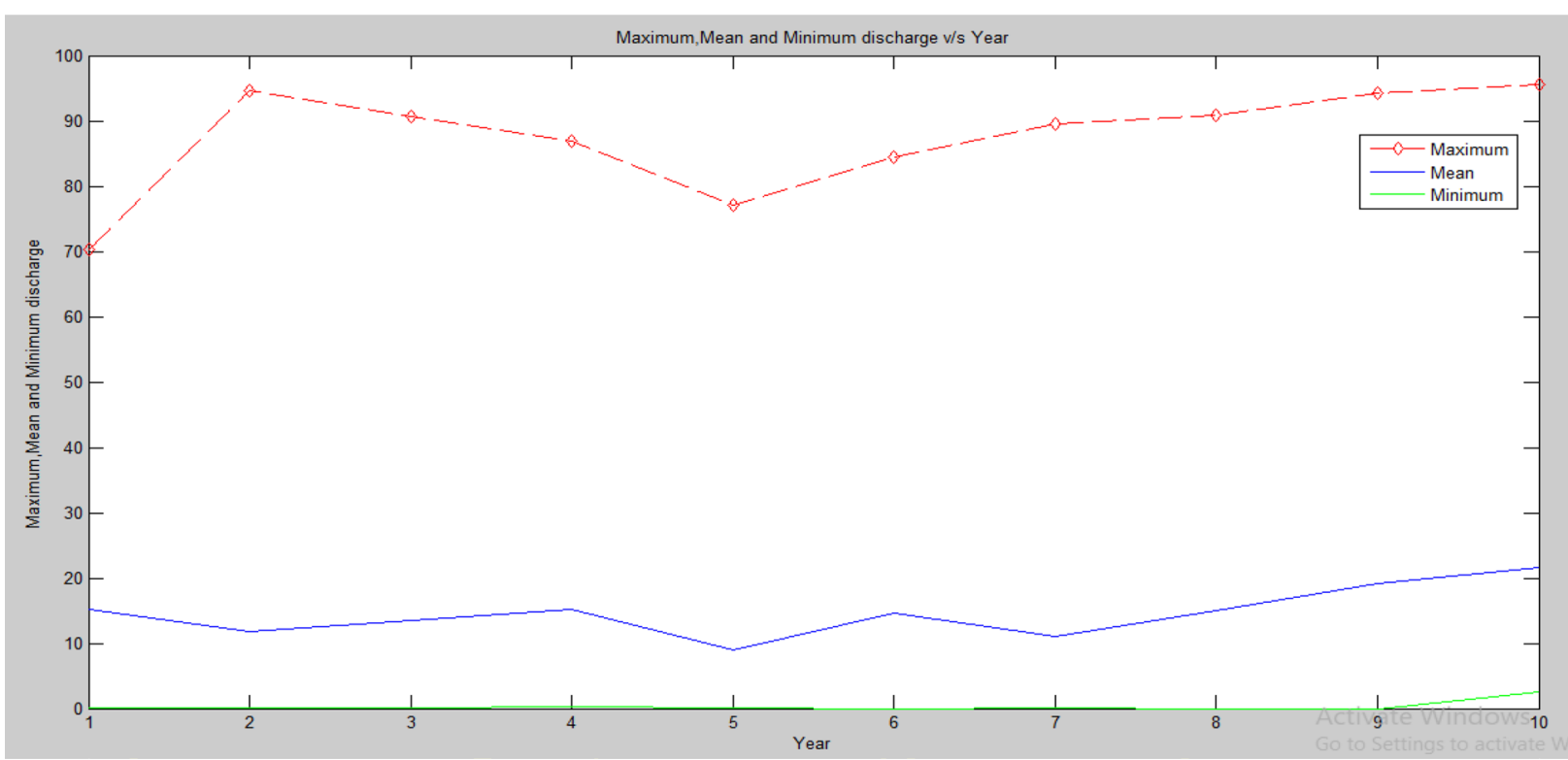

Fig. 3 Curve of maximum, mean and minimum flow discharge $v / s$ year (Fraenkel et al. 1991)

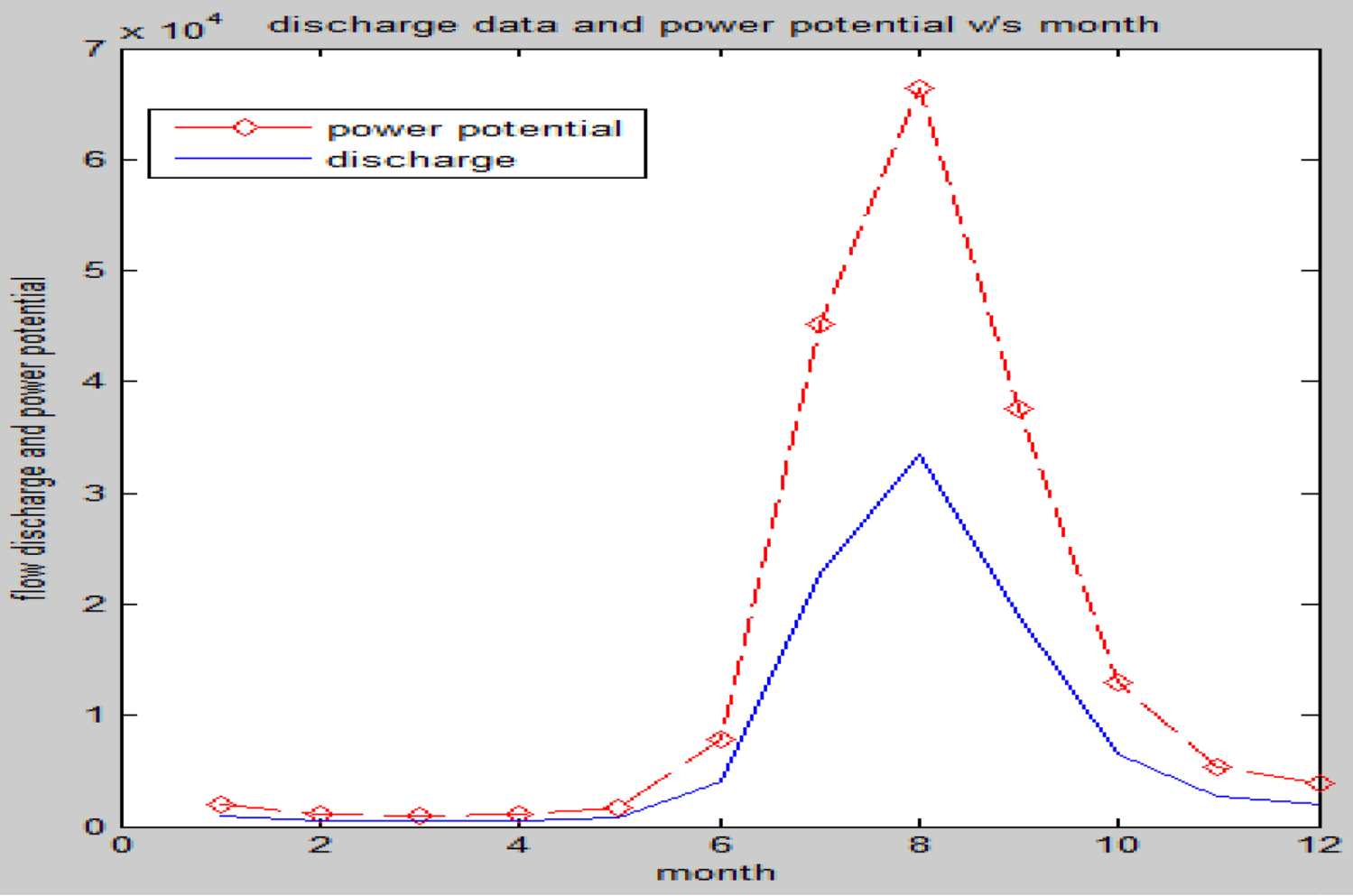

Fig. 4 Curve of power potential and monthly flow release (Fritz 1984) 


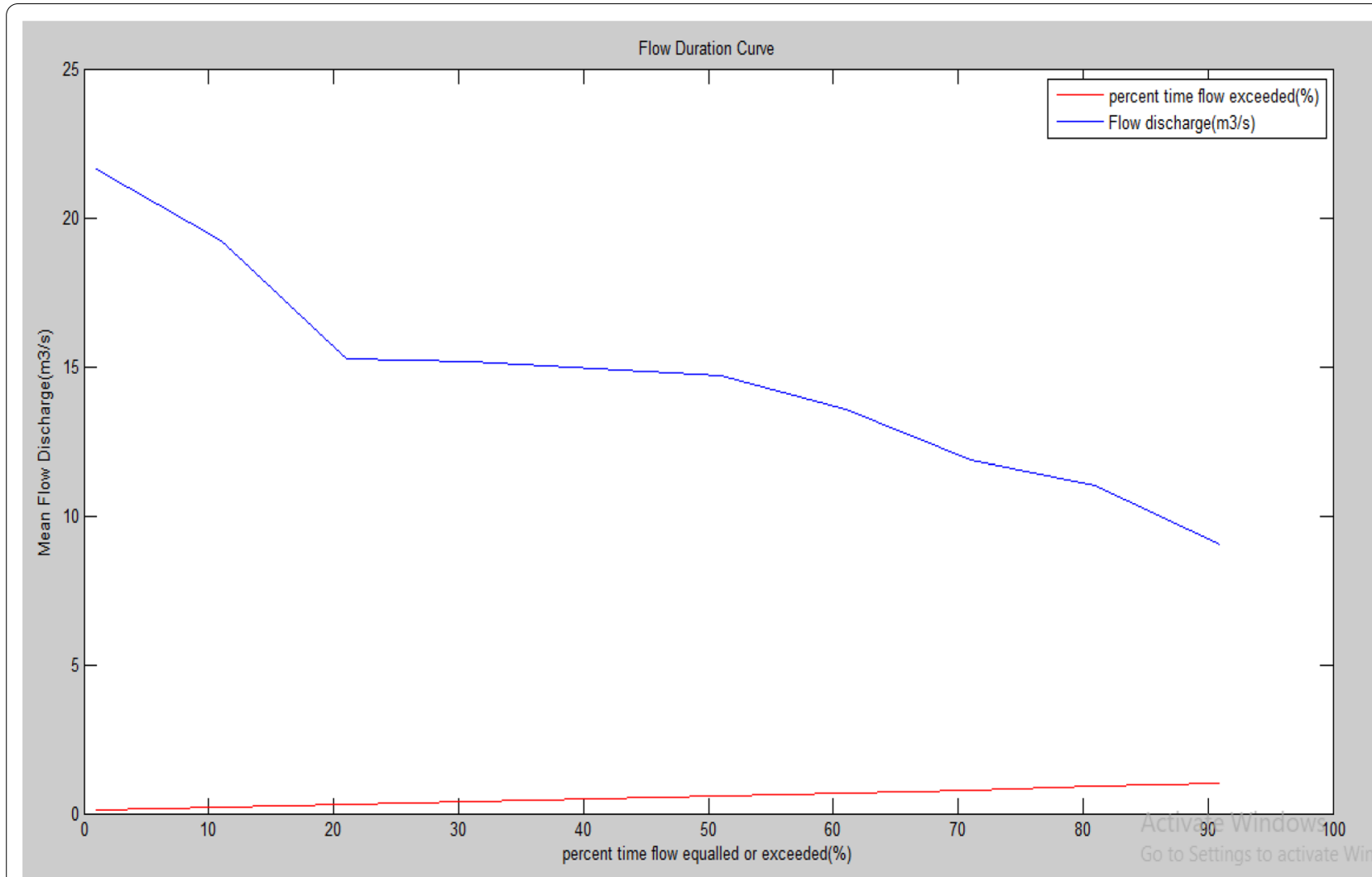

Fig. 5 Flow duration curve for the Ribb River (Karakoyun et al. 2018)

than 90 percent of the time, or that the flow reaches this value in 9 out of 10 years. A small run-of-the-river hydroelectric discharge system can be selected from 90 to $50 \%$ of reliable flow values anywhere.

Curves of flow length describe the flow of streams. They illustrate streamflow rates that have been surpassed by different percentages of the time (often daily mean discharge) (Fig. 4). They refer to a specific location in a stream (site) and represent flow over a given period of time (usually the site record period). The FDC provides data on a river's flow characteristics for a selected area that is subject to all historical river flows (Karakoyun et al. 2018) (Fig. 5).

Figure 5 shows that for the Ribb Dam site, from flow data, month by month, and excess flow over a few months of the year, there is very little flow over the remaining period. Even after deduction of the minimum requirement downstream, the reliable flow tends to be very low (overflow of 90\%), with the exception of the few rainy months of the year. This reality disconcerts the designers of small hydroelectric plants in choosing the optimal design flow.

The maximum, minimum, and average discharges for monthly power and electricity were $33.034 \mathrm{MW}$,
$0.12 \mathrm{MW}$ and $5.53 \mathrm{MW}$, respectively. The annual average electricity production was 46,026.159 MWh (Fig. 3).

Hydroelectricity is Ethiopia's main source of energy that can meet the energy needs of the people. Although the country has enormous hydroelectric potential, only a fraction of it has been exploited till today. This is largely due to the capitalistic nature of hydroelectric projects. Today the hydroelectricity is the most important form of the renewable and sustainable energy (Binder 2000). Small-scale renewable generation could be the most cost-effective way to provide electricity to remote villages that are not connected to transmission lines.

Small-scale hydropower may be built with little to no environmental effects on biodiversity to habitats, in comparison to large-scale hydropower projects, largely because most small hydropower plants are run-of-river projects or are incorporated in existing water infrastructures (Abbasi and Abbasi 2011).

Small-scale hydropower is a promising alternative for generating clean, affordable energy in rural or developing areas because of its flexibility, low investment costs, and as a renewable energy source. Small-scale hydropowerrelated environmental effects are far less than those 
linked to larger operations. The mini-grid system is also appropriate for small-scale hydro power, making it perfect for rural areas (Tarrant and Adhikari 2015).

The key advantages and drawbacks of limited hydropower are.

\section{Advantages}

- A renewable source of electricity, generating no water or air pollution, is small-scale hydropower.

- Tiny hydropower is a source of renewable energy as a non-consumptive use of electricity.

- There is a limited environmental effect on Since no reservoirs are built, small hydropower does not cause reservoir-related issues such as methane emissions, human displacement, sedimentation, and disturbed stream dynamics (for more detail, see fact sheets on large-scale hydropower and man-made reservoirs).

\section{Disadvantages}

- To be economical, energy consumers need to be located near the hydropower scheme, thus limiting the application of small-scale hydropower to streamside communities.

- The streamflow limits power generation. Every small hydropower plant has a maximum capacity, determined by the streamflow, which cannot be exceeded.

- Seasonal variation in streamflow causes variation and disturbance in energy supply. In order to ensure adequate energy generation throughout the year, advanced planning is required, especially in areas with a severe dry season.

\section{Conclusion}

A river profile was established from the measurement data, with a height of $73.3 \mathrm{~m}$, a head loss $70.37 \mathrm{~m}$ and an output power of $5.53 \mathrm{MW}$ was also deducted. This study shows that River Ribb has a potential for the production of small hydropower plants both for the sustainable and renewable source of electricity. Access to a crucial pillar for human well-being, sustainable growth, and poverty alleviation is small hydropower. An ongoing and pressing problem for global development is ensuring that everybody has adequate access. Balancing the challenge between development and environment therefore provides us with an ultimate goal of ensuring everyone has access to enough sustainable energy to maintain a high standard of living.

The deployment potential for the construction of small power plants in remote and mountainous areas will help to create rural and remote areas. The use of this renewable energy source in these regions allows for economic, and social growth and other benefits in regions where small factories such as irrigation, water supply, tourism, fishing and flood prevention are built. Evaluating hydroproject interactions can help assess the future effects of such projects. The results of the study should include a set of recommendations for better planning, development work, and the execution of the Ribb Hydroelectric Project dam.

Thus, the results of the study will help policy makers and planners, scientists, social workers, organizations, and researchers run programs. The Ethiopian government has set ambitious targets to become a middle-income country by 2025 , which includes targets for power generation and aggressive connections.

\section{Recommendation}

This study evaluated the existing Ribb dam for electricity production, and recommends the development of water resources for multiple purposes. Further, the recommendation of such hydroelectric dams will benefit the country want sustainable development. To be effective and efficient in programming rural electrification by developing small hydropower plants, it must be combined with the broader objectives of other rural development programs at local and national levels. The top most priority has to be given among the various factors that influence the cost of capital, the choice of site and the simple layout. Develop and modernize legacy conventional recording systems for hydraulic data in regular irrigation systems and incorporate modern technology to improve data recording operations.

\section{Abbreviations}

SHP: Small hydropower; FDC: Flow Duration Curve.

\section{Acknowledgments}

The authors thank Tesfa G. for providing data related to the case study and Asrat T. is gratefully acknowledged for their comments and suggestions on the language. The Ministry of Irrigation, Water and Energy (MIWE) is also acknowledged.

\section{Authors' contributions}

The author has conducted all research activities such as data acquisition, analysis, evaluation, and results. The author read and approved the final manuscript.

\section{Funding}

No funding was received.

\section{Availability of data and materials}

The data used for this study mentioned with their sources; if data used in the manuscript are not precise, the author is ready to clarify and even send the dataset on request.

Ethics approval and consent to participate Not applicable. 


\section{Consent for publication}

I agreed to submit the final manuscript for Environmental Systems Research Journal.

\section{Competing interests}

The author declares that they have no competing interests.

Received: 3 September 2020 Accepted: 26 October 2020

Published online: 01 January 2021

\section{References}

Abbasi T, Abbasi SA (2011) Small hydro and the environmental implications of its extensive utilization. Renew Sustain Energy Rev 15(4):2134-2143

Bartle A (2002) Hydropower potential and development activities. Energy Policy 30(14):1231-1239

Binder, J. (2000). Small Hydroelectric Power Plants: A Most Efficient Contribution to Renewable Energy. Karntner Elektrizitats Aktiengesellschaft (KELAG). Sixty International Summer Schools Solar Energy. ApplicationsSustainable Energy Issues, University of Klagenfurt. Klagenfurt/Carinthia Austria, 204-214.

Christoff P (2016) The promissory note: COP 21 and the Paris Climate Agreement. Environmental Politics 25(5):765-787

Derbew D 2013 Ethiopia's Renewable Energy Power Potential and Development Opportunities Ministry of Water and Energy Abu Dhabi

Du J, Yang H, Shen Z, Chen J (2017) Micro hydropower generation from water supply system in high rise buildings using the pump as turbines. Energy 137:431-440

ESHA_European Small Hydropower Association (2004). Guide on How to Develop a Small Hydropower Plant, Chapter 1, Introduction.

Floriancic M, Margreth M, Naef F. (2016). What can we learn about low flow storage properties from flow duration curves? In EGU General Assembly Conference Abstracts (Vol. 18).

Fraenkel P, Paish O, Bokalders V, Harvey A, Brown A, Edwards R. (1991). Microhydro Power. Intermediate Technology.
Fritz, J. J. (1984). Small and mini-hydropower systems: resource assessment and project feasibility.

Girma, Z. (2016). Techno-economic feasibility of small scale hydropower in Ethiopia: The case of the kulfo River, in Southern Ethiopia. Journal of Renewable Energy, 2016.

Karakoyun Y, Yumurtacı Z, Dönmez A. H. (2018). Environmental Flow Assessment Methods: A Case Study. In Exergetic, Energetic and Environmental Dimensions (pp. 1061-1074). Academic Press.

Kaunda CS, Kimambo CZ, Nielsen TK. 2012 Potential of small-scale hydropower for electricity generation in Sub-Saharan Africa ISRN Renewable Energy

Khan AA, Shahzad A, Hayat I, Miah MS (2016) Recovery of flow conditions for optimum electricity generation through micro-hydro turbines. Renewable Energy 96:940-948

Kumar A, Shankar V 2009. SHP Development in India. In 5th Hydro Power for Today Forum.

KUmar P 2018. Socio-economic impact of hydroelectric power projects in Himachal Pradesh a study of the Satluj river basin.

Quigley C (2013) An Assessment of Hydroelectric Feasibility at Colonel Charles D. Maynard Dam in Tucker, Arkansas

Sule BF, Salami AW, Bilewu SO, Adeleke OO, Ajimotokan HA (2011) Hydrology of River Oyun and Hydropower Potential of Unilorin Dam, Ilorin, Kwara State. Nigeria New York Sci J 4(1):69-78

Tarrant J Adhikari D 2015 Nepal Post-Earthquake Potential for Renewable Energy Investments for Climate Resilient Development.

Woldemariam, WG 2004 The Potential Contribution of Renewables in Ethiopia's Energy Sector: An Analysis of Geothermal and Cogeneration Technologies.

Yüksel I (2009) Dams and hydropower for sustainable development. Energy Sources, Part B 4(1):100-110

\section{Publisher's Note}

Springer Nature remains neutral with regard to jurisdictional claims in published maps and institutional affiliations.

\section{Submit your manuscript to a SpringerOpen ${ }^{\circ}$ journal and benefit from:}

- Convenient online submission

- Rigorous peer review

- Open access: articles freely available online

- High visibility within the field

- Retaining the copyright to your article

Submit your next manuscript at springeropen.com 